\title{
Pengaruh Ekstrak Bawang Hitam Terhadap Penurunan Kadar Glukosa Darah Pada Mencit
}

\author{
Pipit Festi Wiliyanarti ${ }^{1}$, Metro Gali Wahyullah ${ }^{1}$ \\ ${ }^{1)}$ Departemen Keperawatan Komunitas FIK UM Surabaya \\ Pipitfesti@fik.um-surabaya.ic.id
}

\begin{abstract}
Tanggal Submit:

26 Januari 2021

Tanggal Review:

22 Februari 2021

Tanggal Publish

Online: 18 Juni 2021

Administration of oral hypoglycemic drugs and insulin is one of the most common pharmacological treatments given to people with diabetes mellitus. This treatment is carried out in the long term so that it causes side effects and is carried out continuously so that it will affect the financial condition of the diabetes mellitus patient. The purpose of this study was to determine the effect of black garlic extract on decreasing blood glucose levels in mice (mus musculus). This study uses the design of True Experimental design (pretest-posttest with control group design). The population is mice in Pusvetma Surabaya. Sampling method uses Non Probability Sampling Purposive Sampling type. Samples taken were 30 mice consisting of 15 intervention groups and 15 control groups. Data was collected using observation sheets, then analyzed using Independent sample $t$ test and Dependent sample t test with a significance level of 5 0.05. The results showed: Using the test Independent sample T test obtained a significance value $\rho=0,000$ It can be concluded that there is an effect of black onion extract to reduce blood glucose levels in mice. In the paired t-test test in the treatment group showed $\rho=0,000$ that there were differences in blood glucose levels before being given extracts of garlic and after being given intervention. It is expected that black garlic can be used as an alternative medicine to reduce blood glucose levels.
\end{abstract}

Keyword : Ekstrak of black garlic, Blood sugar levels, mus musculus

\section{PENDAHULUAN}

Peningkatan kadar glukosa

darah (Hiperglikemia) adalah keadaan dimana kadar glukosa dalam darah lebih dari $125 \mathrm{mg} / \mathrm{dl}$, pada kondisi ini keseimbangan kadar gula darah terkadang tidak bisa terkontrol dengan baik hanya melalui makan sehat dan olahraga teratur, tapi membutuhkan obat-obatan untuk menjaga kadar gulahnya agar tetap normal (PERKENI, 2015). Pada saat ini, pemberian insulin adalah salah satu penatalaksanaan farmakologis yang paling umum diberikan pada penderita diabetes mellitus. Pengobatan ini dilakukan dalam jangka waktu panjang sehingga menimbulkan efek samping dan 
dilakukan secara terus menerus sehingga akan berdampak pada finansial pasien diabetes mellitus tersebut, karena biaya pengobatan diabetes mellitus membutuhkan biaya yang besar dan dosisnya selalu bertambah (Ernawati, 2013).

$$
\text { Berdasarkan Organisasi }
$$

kesehatan dunia WHO (World Health Organisation) memperkirakan jumlah penderita Diabetes di Indonesia akan terus melonjak, dari semula 8,4 juta penderita di tahun 2000 menjadi sekitar 21,3 juta penderita Diabetes Mellitus di tahun 2030. Menurut International Diabetes Federation (IDF) 2015 di dapatkan jumlah penderita Diabetes Mellitus berjumlah 415 juta, dan diperkirakan akan terus meningkat pada tahun 2040 sekitar 642 juta (55\%). Kali ini di Indonesia disebut telah bergeser naik, dari peringkat ke-7 menjadi peringkat ke-5. Berdasarkan data Riset Kesehatan Dasar (Riskesdas) di Indonesia terdapat 10 juta orang penderita diabetes, dan 17,9 juta orang yang berisiko menderita penyakit ini. Sementara pada tingkat provinsi khususnya Jawa Timur, merupakan salah satu wilayah dengan prevalensi penderita DM sebesar 6,8\% dan merupakan penyakit terbanyak nomor dua setelah hipertensi (RISKESDAS, 2018).
Kadar gula darah meningkat di sebabkan oleh beberapa faktor diantaranya karbohidrat, aktivitas fisik, penggunaan obat, keadaan sakit, stress, siklus menstruasi, dehidrasi, mengkonsumsi alkohol, keadaan tersebut akan mengakibatkan penurunan pengambilan glukosa karena menurunnya sensitivitas reseptor insulin serta menurunnya produksi insulin, jika hal tersebut dibiarkan mengakibatkan hiperglikemia. Jika Hiperglikemia dibiarkan akan menyebabkan komplikasi pada organ tubuh, yaitu komplikasi akut dan kronik, Komplikasi akut umumnya timbul akibat glukosa darah yang terlalu rendah (hipoglikemia) atau terlalu tinggi (hiperglikemia).

Adapun penatalaksanaan diabetes mellitus yang yang merupakan upaya mencegah timbulnya komplikasi yaitu edukasi, terapi gizi medis, latihan jasmani, obat farmakologis, dan non medis (Edwina, 2015).

Pengobatan diabetes mellitus adalah pengobatan menahun dan seumur hidup. Pengobatan diabetes mellitus seperti penggunaan insulin dan obat antidiabetes oral harganya relatif lebih mahal karena penggunaannya dalam jangka waktu lama dan dapat menimbulkan efek samping yang tidak diinginkan. Oleh karena itu, perlu dicari obat yang efektif, efek samping yang relatif rendah dan obat dengan harga 
yang murah (Dalimartha dan Adrian,

2012; Kasengke, 2015). Salah satu upaya dalam penanganan diabetes mellitus adalah dengan menggunakan tumbuhan sebagai obat alternatif. Salah satu tumbuhan yang berefek sebagai antidiabetes mellitus adalah bawang hitam. Bawang hitam adalah bawang putih segar (Allium sativum L.) yang telah di panaskan untuk jangka waktu pada suhu tinggi terkontrol $\left(60-90{ }^{\circ} \mathrm{C}\right)$ dengan kelembaban tinggi terkontrol (80-90\%). Bila dibandingkan dengan bawang putih segar, bawang hitam tidak mengeluarkan rasa ofensif yang kuat karena berkurangnya kadar allicin. Peningkatan bioaktivitas bawang putih hitam dibandingkan dengan bawang putih segar dikaitkan dengan perubahan sifat fisikokimia. Bawang hitam memiliki nutrisi yang lebih kaya dan aktivitas biologis yang meningkat, dan prospek aplikasi yang lebih luas (Jung et al., 2014). Total konten fenolik dalam bawang hitam 5-8 kali lebih tinggi dari bawang putih segar, sehingga bawang putih hitam memiliki aktivitas antioksidan lebih tinggi dari bawang putih segar (Kim et al., 2013). Sedangkan jumlah SAC pada bawang hitam juga 5-6 kali lebih tinggi dari bawang putih (Sato, Kohno, \& Hamano, 2006; Wang et al., 2010). Sebuah studi lain juga melaporkan bahwa kandungan dari bawang hitam seperti propil disulfida, SAC dan sulfoxide mampu meningkatkan sensitifitas kadar insulin dalam darah. Pada penelitian sebelumnya mengkonsumsi bawang putih bisa menurunkan glukosa serum sebesar $8,7 \%$ pada tikus sedangkan bawang hitam menurunkan secara signifikan model penilaian homeostasis resistensi insulin (HOMA-IR) sebesar 11,0 dan cenderung menurunkan kadar glukosa serum (Seo et al, 2009).

Selain itu penelitian yang dilakukan oleh Faisma Rosita (2016), mengenai pengaruh ekstrak bawang hitam (black garlic) untuk menurunkan kadar gula darah pada mencit berdasarkan lama pemanasan. Penelitian ini menunjukkan bahwa ekstrak bawang hitam mengandung senyawa allicin dan SAC sebagai antioksidan. Sedangkan hasil dinyatakan bahwa ekstrak bawang hitam memiliki aktifitas penurunan kadar gula darah, namun belum efektif untuk menurunkan kadar gula darah jika dibandingkan dengan glibenklamid.

Berdasarkan hal tersebut perlu dianalisis pengaruh pemberian ekstrak bawang hitam (Black Garlic) terhadap penurunan kadar glukosa darah pada mencit (Mus Musculus)”.

\section{METODE PENELITIAN}

Pada penelitian ini merupakan

True Exsprerimental menggunakan Design Pretest-Posttest Control Group 
Design. Pada kedua kelompok diawali dengan (pre-test), dan setelah pemberian perlakuan selesai diadakan pengukuran kembali (post-test)(Nursalam, 2016)

Populasi dalam penelitian ini adalah mencit di Pusvetma. Teknik sampling dalam penelitian ini adalah purposive sampling. Sampel dalam penelitian ini adalah 32 mencit yang sesuai kriteria yaitu Jenis kelamin yang di pilih untuk sampel adalah berjenis kelamin jantan, berumur 2 bulan dengan berat badan 20-30 gram dan dalam keadaan sehat. Instrumen yang digunakan dalam penelitian ini adalah SOP, Lembar Observasi, alat ukur kadar glukosa darah.

Teknik analisis yang digunakan dalam penelitian ini adalah uji $T$ independent sample tes dan dependent sample test. sebelum dilakukan $\mathrm{Uji}$ Independent sample $T$ test dan dependent $t$ test menggunakan software statistic data harus terlebih dahulu dilakukan uji normalitas menggunakan uji kolmogorov-smirnov dengan nilai kemaknaan $\rho>\alpha=0,05$

\section{HASIL}

\section{Karakteristik Hewan coba}

Jenis kelamin hewan coba yang di pilih untuk sampel adalah berjenis kelamin jantan, berumur 2 bulan dengan berat badan 20-30 gram dan dalam keadaan sehat.

\section{Data Khusus}

Identifikasi Kadar Glukosa Darah Sebelum Dan Sesudah Di Berikan Intervensi Ekstrak Bawang Hitam Pada Kelompok Perlakuan.

Tabel 1 Kadar glukosa darah sebelum dan sesudah diberikan intervensi pada kelompok

\begin{tabular}{cccc}
\multicolumn{4}{c}{ perlakuan. } \\
\hline Kode & Kadar & Kadar & Selisih \\
Sampel & Gula & Gula & $\left.\mathrm{X}_{2}-\mathrm{X}_{1}\right)$ \\
& Darah & Darah & \\
& $\begin{array}{c}\text { Pretest } \\
\left(\mathrm{X}_{1}\right)\end{array}$ & $\begin{array}{c}\text { Posttest } \\
\left(\mathrm{X}_{2}\right)\end{array}$ \\
\hline P1 & 181 & 114 & -67 \\
& $\mathrm{mg} / \mathrm{dl}$ & $\mathrm{mg} / \mathrm{dl}$ & \\
P2 & 179 & 128 & -51 \\
& $\mathrm{mg} / \mathrm{dl}$ & $\mathrm{mg} / \mathrm{dl}$ & \\
P3 & 192 & 145 & -47 \\
& $\mathrm{mg} / \mathrm{dl}$ & $\mathrm{mg} / \mathrm{dl}$ & \\
P4 & 226 & 153 & -43 \\
& $\mathrm{mg} / \mathrm{dl}$ & $\mathrm{mg} / \mathrm{dl}$ & \\
P5 & 190 & 128 & -62 \\
& $\mathrm{mg} / \mathrm{dl}$ & $\mathrm{mg} / \mathrm{dl}$ & \\
P6 & 176 & 108 & -68 \\
& $\mathrm{mg} / \mathrm{dl}$ & $\mathrm{mg} / \mathrm{dl}$ & \\
P7 & 230 & 179 & -51 \\
& $\mathrm{mg} / \mathrm{dl}$ & $\mathrm{mg} / \mathrm{dl}$ &
\end{tabular}




\begin{tabular}{cccc} 
P8 & 187 & 136 & -51 \\
& $\mathrm{mg} / \mathrm{dl}$ & $\mathrm{mg} / \mathrm{dl}$ & \\
P9 & 232 & 185 & -47 \\
& $\mathrm{mg} / \mathrm{dl}$ & $\mathrm{mg} / \mathrm{dl}$ & \\
P10 & 189 & 125 & -64 \\
& $\mathrm{mg} / \mathrm{dl}$ & $\mathrm{mg} / \mathrm{dl}$ & \\
P11 & 192 & 103 & -89 \\
& $\mathrm{mg} / \mathrm{dl}$ & $\mathrm{mg} / \mathrm{dl}$ & \\
P12 & 192 & 123 & -69 \\
& $\mathrm{mg} / \mathrm{dl}$ & $\mathrm{mg} / \mathrm{dl}$ & \\
P13 & 214 & 156 & -58 \\
& $\mathrm{mg} / \mathrm{dl}$ & $\mathrm{mg} / \mathrm{dl}$ & \\
P14 & 234 & 181 & -53 \\
& $\mathrm{mg} / \mathrm{dl}$ & $\mathrm{mg} / \mathrm{dl}$ & \\
P15 & 181 & 110 & -71 \\
& $\mathrm{mg} / \mathrm{d} l$ & $\mathrm{mg} / \mathrm{dl}$ & \\
P16 & 185 & 107 & -78 \\
& $\mathrm{mg} / \mathrm{dl}$ & $\mathrm{mg} / \mathrm{dl}$ & \\
\hline $\mathrm{N}$ & 16 & 16 & 16 \\
Total & 3180 & 2181 & -999 \\
Mean & 198,75 & 136,3125 & $-62,4375$ \\
SD & 20,77338 & 27,48992 & 12,13243 \\
\hline & & &
\end{tabular}

Berdasarkan hasil penelitian

pada kelompok perlakuan menunjukkan bahwa kadar glukosa darah tertinggi sebelum diberikan intervensi adalah 234 mg/dl dan kadar glukosa darah terendah sebelum diberikan intervensi adalah 176 mg/dl sedangkan kadar glukosa darah tertinggi sesudah diberikan intervensi adalah $185 \mathrm{mg} / \mathrm{dl}$ dan kadar glukosa darah terendah sesudah diberikan intervensi adalah $103 \mathrm{mg} / \mathrm{dl}$. Nilai ratarata kadar glukosa darah sebelum diberikan intervensi yaitu 198,75 sedangkan nilai rata-rata kadar glukosa darah sesudah diberikan intervensi yaitu 136,3125. Pada penelitian ini dari 16 mencit ( $100 \%)$ sebelum diberikan intervensi semua kadar glukosa darah mencit tinggi (hiperglikemia) sedangkan dari 16 mencit (100\%) sesudah diberikan intervensi 13 mencit $(81,2 \%)$ mengalami penurunan kadar glukosa ke dalam batas normal dan 3 mencit ( $18,8 \%$ ) mengalami penurunan kadar glukosa darah tapi belum ke dalam batas normal . Selisih penurunan kadar glukosa darah tertinggi yaitu sebesar 89 $\mathrm{mg} / \mathrm{dl}$ dan selisih penurunan kadar glukosa darah terendah yaitu $47 \mathrm{mg} / \mathrm{dl}$.

Identifikasi Kadar Glukosa Darah Sebelum Dan Sesudah Di Berikan Intervensi Ekstrak Bawang Hitam Pada Kelompok Kontrol. 
Tabel 2 Kadar glukosa darah sebelum dan sesudah tanpa diberikan intervensi pada kelompok kontrol

\begin{tabular}{|c|c|c|c|}
\hline $\begin{array}{c}\text { Kode } \\
\text { Sampel }\end{array}$ & $\begin{array}{l}\text { Kadar Gula Darah } \\
\text { Pretest }\left(\mathrm{X}_{1}\right)\end{array}$ & $\begin{array}{l}\text { Kadar Gula Darah } \\
\text { Posttest }\left(\mathrm{X}_{2}\right)\end{array}$ & Selisih $\left.X_{2}-X_{1}\right)$ \\
\hline K1 & $222 \mathrm{mg} / \mathrm{dl}$ & $194 \mathrm{mg} / \mathrm{dl}$ & -28 \\
\hline K2 & $185 \mathrm{mg} / \mathrm{dl}$ & $179 \mathrm{mg} / \mathrm{dl}$ & -6 \\
\hline K3 & $183 \mathrm{mg} / \mathrm{dl}$ & $178 \mathrm{mg} / \mathrm{dl}$ & -5 \\
\hline K4 & $180 \mathrm{mg} / \mathrm{dl}$ & $176 \mathrm{mg} / \mathrm{dl}$ & -4 \\
\hline K5 & 197 mg/dl & $187 \mathrm{mg} / \mathrm{dl}$ & -10 \\
\hline K6 & 209 mg/dl & $200 \mathrm{mg} / \mathrm{dl}$ & -9 \\
\hline K7 & $186 \mathrm{mg} / \mathrm{dl}$ & $179 \mathrm{mg} / \mathrm{dl}$ & -7 \\
\hline K8 & $190 \mathrm{mg} / \mathrm{dl}$ & $186 \mathrm{mg} / \mathrm{dl}$ & -4 \\
\hline K9 & $212 \mathrm{mg} / \mathrm{dl}$ & $205 \mathrm{mg} / \mathrm{dl}$ & -7 \\
\hline K10 & 197 mg/dl & $188 \mathrm{mg} / \mathrm{dl}$ & -9 \\
\hline K11 & $186 \mathrm{mg} / \mathrm{dl}$ & $174 \mathrm{mg} / \mathrm{dl}$ & -12 \\
\hline K12 & 194 mg/dl & $189 \mathrm{mg} / \mathrm{dl}$ & -5 \\
\hline K13 & $179 \mathrm{mg} / \mathrm{dl}$ & $176 \mathrm{mg} / \mathrm{dl}$ & -3 \\
\hline K14 & $188 \mathrm{mg} / \mathrm{dl}$ & $180 \mathrm{mg} / \mathrm{dl}$ & -8 \\
\hline K15 & $192 \mathrm{mg} / \mathrm{dl}$ & $181 \mathrm{mg} / \mathrm{dl}$ & -11 \\
\hline K16 & $199 \mathrm{mg} / \mathrm{dl}$ & $183 \mathrm{mg} / \mathrm{dl}$ & -16 \\
\hline $\mathrm{N}$ & 16 & 16 & 16 \\
\hline Total & 3099 & 2955 & -144 \\
\hline Mean & 193,6875 & 184,6875 & -9 \\
\hline SD & 12,0594 & 8,882333 & 6,110101 \\
\hline
\end{tabular}

Berdasarkan hasil penelitian pada kelompok kontrol menunjukkan bahwa kadar glukosa darah tertinggi sebelum tanpa diberikan intervensi adalah $222 \mathrm{mg} / \mathrm{dl}$ dan kadar glukosa darah terendah sebelum tanpa diberikan intervensi adalah $179 \mathrm{mg} / \mathrm{dl}$ sedangkan kadar glukosa darah tertinggi sesudah tanpa diberikan intervensi adalah 200 $\mathrm{mg} / \mathrm{dl}$ dan kadar glukosa darah terendah sesudah diberikan intervensi adalah 174 $\mathrm{mg} / \mathrm{dl}$. Nilai rata-rata kadar glukosa darah sebelum tanpa diberikan intervensi yaitu 193,6875 sedangkan nilai rata-rata kadar glukosa darah sesudah tanpa diberikan intervensi yaitu 184,6875. Pada penelitian ini dari 16 mencit ( $100 \%)$ sebelum tanpa diberikan intervensi semua kadar glukosa darah mencit tinggi (hiperglikemia) sedangkan dari 16 mencit ( $100 \%$ ) sesudah tanpa diberikan intervensi 1 mencit (6,2\%) mengalami penurunan kadar glukosa ke dalam batas normal dan 15 mencit ( $93,8 \%$ ) mengalami penurunan kadar glukosa darah tapi belum ke dalam batas normal . Selisih penurunan kadar glukosa darah tertinggi yaitu sebesar $28 \mathrm{mg} / \mathrm{dl}$ dan selisih penurunan kadar glukosa darah terendah yaitu $3 \mathrm{mg} / \mathrm{dl}$. 


\section{Analisis Pemberian Ekstrak Bawang \\ Glukosa Darah Pada Mencit.}

\section{Hitam Terhadap Penurunan Kadar}

Tabel 3 Analisis pengaruh ekstrak bawang hitam terhadap penurunan kadar glukosa darah pada mencit

\begin{tabular}{|c|c|c|c|}
\hline $\begin{array}{l}\text { Kode } \\
\text { Sampel }\end{array}$ & $\begin{array}{l}\text { Selisih } \\
\text { penurunan } \\
\text { kadar } \\
\text { glukosa } \\
\text { darah } \\
\text { pada } \\
\text { kelompok } \\
\text { perlakuan }\end{array}$ & $\begin{array}{l}\text { Kode } \\
\text { Sampel }\end{array}$ & $\begin{array}{l}\text { Selisih } \\
\text { penurunan } \\
\text { kadar } \\
\text { glukosa } \\
\text { darah } \\
\text { pada } \\
\text { kelompok } \\
\text { control }\end{array}$ \\
\hline P1 & $-67 \mathrm{mg} / \mathrm{dl}$ & K1 & $-28 \mathrm{mg} / \mathrm{dl}$ \\
\hline $\mathrm{P} 2$ & $-51 \mathrm{mg} / \mathrm{dl}$ & K2 & $-6 \mathrm{mg} / \mathrm{dl}$ \\
\hline P3 & $-47 \mathrm{mg} / \mathrm{dl}$ & K3 & $-5 \mathrm{mg} / \mathrm{dl}$ \\
\hline $\mathrm{P} 4$ & $-73 \mathrm{mg} / \mathrm{dl}$ & K4 & $-4 \mathrm{mg} / \mathrm{dl}$ \\
\hline P5 & $-62 \mathrm{mg} / \mathrm{dl}$ & K5 & $-10 \mathrm{mg} / \mathrm{dl}$ \\
\hline P6 & $-68 \mathrm{mg} / \mathrm{dl}$ & K6 & $-9 \mathrm{mg} / \mathrm{dl}$ \\
\hline P7 & $-51 \mathrm{mg} / \mathrm{dl}$ & K7 & $-7 \mathrm{mg} / \mathrm{dl}$ \\
\hline P8 & $-51 \mathrm{mg} / \mathrm{dl}$ & K8 & $-4 \mathrm{mg} / \mathrm{dl}$ \\
\hline P9 & $-47 \mathrm{mg} / \mathrm{dl}$ & K9 & $-7 \mathrm{mg} / \mathrm{dl}$ \\
\hline P10 & $-64 \mathrm{mg} / \mathrm{dl}$ & K10 & $-9 \mathrm{mg} / \mathrm{dl}$ \\
\hline P11 & $-89 \mathrm{mg} / \mathrm{dl}$ & K11 & $-12 \mathrm{mg} / \mathrm{dl}$ \\
\hline P12 & $-69 \mathrm{mg} / \mathrm{dl}$ & K12 & $-5 \mathrm{mg} / \mathrm{dl}$ \\
\hline P13 & $-58 \mathrm{mg} / \mathrm{dl}$ & K13 & $-3 \mathrm{mg} / \mathrm{dl}$ \\
\hline P14 & $-53 \mathrm{mg} / \mathrm{dl}$ & K14 & $-8 \mathrm{mg} / \mathrm{dl}$ \\
\hline P15 & $-71 \mathrm{mg} / \mathrm{dl}$ & K15 & $-11 \mathrm{mg} / \mathrm{dl}$ \\
\hline P16 & $-78 \mathrm{mg} / \mathrm{dl}$ & K16 & $-16 \mathrm{mg} / \mathrm{dl}$ \\
\hline Total & -999 & Total & -144 \\
\hline Mean & $-62,4375$ & Mean & -9 \\
\hline SD & 12,13243 & SD & 6,110101 \\
\hline
\end{tabular}

Berdasarkan hasil penelitian menunjukkan bahwa rata-rata selisih pada kelompok perlakuan yaitu sebesar 62,4375 sedangkan pada kelompok kontrol sebesar -9. Hasil uji statistik menggunakan SPSS dengan Uji independent sample $t$ test, sebelum dilakukan Uji Independent sample T test menggunakan Software statistic data harus terlebih dahulu dilakukan uji normalitas menggunakan uji kolmogorov-smirnov dengan nilai kemaknaan $\rho>\alpha=0,05$ untuk mengetahui apakah data tersebut berdistribusi normal atau tidak. Hasil uji normalitas pada kelompok perlakuan didapatkan nilai signifikansi $(\rho)$ adalah 0.167 Sedangkan pada kelompok kontrol didapatkan nilai signifikansi ( $\rho$ ) adalah 0.200 sehingga berdasarkan uji 
normalitas kolmogorov-smirnov data berdistribusi normal. Hasil dari uji Independent sample $t$ test di dapatkan nilai signifikansi $0,005>\alpha 0,05$ maka dapat di asumsikan berbeda sehingga nilai signifikansi (2-tailed) $0,000<\alpha$
0,05 sehingga terdapat perbedaan antara kelompok perlakuan dan kelompok kontrol terhadap kadar glukosa darah pada mencit (mus musculus).

\section{Analisis Perbedaan Kadar Glukosa Darah Pada Kelompok Perlakuan}

Tabel 4 Analisis perbedaan kadar glukosa darah sebelum dan sesudah pada kelompok

\begin{tabular}{llll}
\multicolumn{3}{c}{ perlakuan } \\
\hline Kode & Kadar Gula Darah & $\begin{array}{l}\text { Kadar Gula Darah } \\
\text { Posttest }\left(\mathrm{X}_{2}\right)\end{array}$ & Selisih $\left.\mathrm{X}_{2}-\mathrm{X}_{1}\right)$ \\
Sampel & Pretest $\left(\mathrm{X}_{1}\right)$ & $114 \mathrm{mg} / \mathrm{dl}$ & -67 \\
\hline P1 & $181 \mathrm{mg} / \mathrm{dl}$ & $128 \mathrm{mg} / \mathrm{dl}$ & -51 \\
P2 & $179 \mathrm{mg} / \mathrm{dl}$ & $145 \mathrm{mg} / \mathrm{dl}$ & -47 \\
P3 & $192 \mathrm{mg} / \mathrm{dl}$ & $153 \mathrm{mg} / \mathrm{dl}$ & -43 \\
P4 & $226 \mathrm{mg} / \mathrm{dl}$ & $128 \mathrm{mg} / \mathrm{dl}$ & -62 \\
P5 & $190 \mathrm{mg} / \mathrm{dl}$ & $108 \mathrm{mg} / \mathrm{dl}$ & -68 \\
P6 & $176 \mathrm{mg} / \mathrm{dl}$ & $179 \mathrm{mg} / \mathrm{dl}$ & -51 \\
P7 & $230 \mathrm{mg} / \mathrm{dl}$ & $136 \mathrm{mg} / \mathrm{dl}$ & -51 \\
P8 & $187 \mathrm{mg} / \mathrm{dl}$ & $185 \mathrm{mg} / \mathrm{dl}$ & -47 \\
P9 & $232 \mathrm{mg} / \mathrm{dl}$ & $125 \mathrm{mg} / \mathrm{dl}$ & -64 \\
P10 & $189 \mathrm{mg} / \mathrm{dl}$ & $103 \mathrm{mg} / \mathrm{dl}$ & -89 \\
P11 & $192 \mathrm{mg} / \mathrm{dl}$ & $123 \mathrm{mg} / \mathrm{dl}$ & -69 \\
P12 & $192 \mathrm{mg} / \mathrm{dl}$ & $156 \mathrm{mg} / \mathrm{dl}$ & -58 \\
P13 & $214 \mathrm{mg} / \mathrm{dl}$ & $181 \mathrm{mg} / \mathrm{dl}$ & -53 \\
P14 & $234 \mathrm{mg} / \mathrm{dl}$ & $110 \mathrm{mg} / \mathrm{dl}$ & -71 \\
P15 & $181 \mathrm{mg} / \mathrm{dl}$ & $107 \mathrm{mg} / \mathrm{dl}$ & -78 \\
P16 & $185 \mathrm{mg} / \mathrm{dl}$ & 16 & 16 \\
\hline N & 16 & 2181 & -999 \\
Total & 3180 & 136,3125 & $-62,4375$ \\
Mean & 198,75 & 27,48992 & 12,13243 \\
SD & 20,77338 & & \\
\hline
\end{tabular}

Uji paired sample t test $\rho=0,000$ $\rho<\alpha 0,05$

Berdasarkan hasil penelitian pada kelompok perlakuan menunjukkan bahwa Pada penelitian ini dari 16 mencit ( $100 \%$ ) sebelum diberikan intervensi semua kadar glukosa darah mencit tinggi (hiperglikemia) sedangkan dari 16 mencit ( $100 \%)$ sesudah diberikan intervensi 13 mencit ( 81,2\%) mengalami penurunan kadar glukosa ke dalam batas normal dan 3 mencit (
$18,8 \%$ ) mengalami penurunan kadar glukosa darah tapi belum ke dalam batas normal . Selisih penurunan kadar glukosa darah tertinggi yaitu sebesar 89 $\mathrm{mg} / \mathrm{dl}$ dan selisih penurunan kadar glukosa darah terendah yaitu $47 \mathrm{mg} / \mathrm{dl}$.

Sebelum dilakukan Uji paired sample $T$ test menggunakan Software statistic, data harus terlebih dahulu dilakukan uji normalitas menggunakan 
uji kolmogorov-smirnov dengan nilai kemaknaan $\rho>\alpha=0,05$ untuk mengetahui apakah data tersebut berdistribusi normal atau tidak. Hasil uji normalitas pada kelompok perlakuan didapatkan nilai signifikansi ( $\rho$ ) adalah 0.167 $(\rho>0.05)$, sehingga berdasarkan uji normalitas kolmogorov-smirnov data berdistribusi normal. Hasil uji statistik menggunakan uji paired t-test pada kelompok perlakuan menunjukkan $\rho=0,000$, dengan tingkat kemaknaan 0,05 maka $\rho=0,000<\alpha 0,05$ sehingga $\mathrm{H}_{1}$ diterima dan $\mathrm{H}_{0}$ ditolak artinya terdapat perbedaan kadar glukosa darah sebelum diberikan ekstrak bawang hitam dan sesudah diberikan ekstrak bawang hitam.

Analisis Perbedaan Kadar Glukosa Darah Pada Kelompok Kontrol

Tabel 5 Analisis perbedaan kadar glukosa darah sebelum dan sesudah pada kelompok kontrol.

\begin{tabular}{llll}
\hline $\begin{array}{l}\text { Kode } \\
\text { Sampel }\end{array}$ & $\begin{array}{l}\text { Kadar Gula Darah } \\
\text { Pretest }\left(\mathrm{X}_{1}\right)\end{array}$ & $\begin{array}{l}\text { Kadar Gula Darah } \\
\text { Posttest }\left(\mathrm{X}_{2}\right)\end{array}$ & Selisih $\left.\mathrm{X}_{2}-\mathrm{X}_{1}\right)$ \\
\hline $\mathrm{K} 1$ & $222 \mathrm{mg} / \mathrm{dl}$ & $194 \mathrm{mg} / \mathrm{dl}$ & -28 \\
$\mathrm{~K} 2$ & $185 \mathrm{mg} / \mathrm{dl}$ & $179 \mathrm{mg} / \mathrm{dl}$ & -6 \\
$\mathrm{~K} 3$ & $183 \mathrm{mg} / \mathrm{dl}$ & $178 \mathrm{mg} / \mathrm{dl}$ & -5 \\
$\mathrm{~K} 4$ & $180 \mathrm{mg} / \mathrm{dl}$ & $176 \mathrm{mg} / \mathrm{dl}$ & -4 \\
$\mathrm{~K} 5$ & $197 \mathrm{mg} / \mathrm{dl}$ & $187 \mathrm{mg} / \mathrm{dl}$ & -10 \\
$\mathrm{~K} 6$ & $209 \mathrm{mg} / \mathrm{dl}$ & $200 \mathrm{mg} / \mathrm{dl}$ & -9 \\
$\mathrm{~K} 7$ & $186 \mathrm{mg} / \mathrm{dl}$ & $179 \mathrm{mg} / \mathrm{dl}$ & -7 \\
$\mathrm{~K} 8$ & $190 \mathrm{mg} / \mathrm{dl}$ & $186 \mathrm{mg} / \mathrm{dl}$ & -4 \\
$\mathrm{~K} 9$ & $212 \mathrm{mg} / \mathrm{dl}$ & $205 \mathrm{mg} / \mathrm{dl}$ & -7 \\
$\mathrm{~K} 10$ & $197 \mathrm{mg} / \mathrm{dl}$ & $188 \mathrm{mg} / \mathrm{dl}$ & -9 \\
$\mathrm{~K} 11$ & $186 \mathrm{mg} / \mathrm{dl}$ & $174 \mathrm{mg} / \mathrm{dl}$ & -12 \\
$\mathrm{~K} 12$ & $194 \mathrm{mg} / \mathrm{dl}$ & $189 \mathrm{mg} / \mathrm{dl}$ & -5 \\
$\mathrm{~K} 13$ & $179 \mathrm{mg} / \mathrm{dl}$ & $176 \mathrm{mg} / \mathrm{dl}$ & -3 \\
K14 & $188 \mathrm{mg} / \mathrm{dl}$ & $180 \mathrm{mg} / \mathrm{dl}$ & -8 \\
$\mathrm{~K} 15$ & $192 \mathrm{mg} / \mathrm{dl}$ & $181 \mathrm{mg} / \mathrm{dl}$ & -11 \\
K16 & $199 \mathrm{mg} / \mathrm{dl}$ & $183 \mathrm{mg} / \mathrm{dl}$ & -16 \\
\hline N & 16 & 16 & 16 \\
Total & 3099 & 2955 & -144 \\
Mean & 193,6875 & 184,6875 & -9 \\
SD & 12,0594 & 8,882333 & 6,110101 \\
\hline
\end{tabular}

Uji Paired sample t test $\rho=0,0333$ $\rho>\alpha 0,05$

Berdasarkan hasil penelitian dari

16 mencit pada kelompok kontrol menunjukkan bahwa Pada penelitian ini dari 16 mencit (100\%) sebelum tanpa diberikan intervensi semua kadar glukosa darah mencit tinggi (hiperglikemia)

sedangkan dari 16 mencit ( $100 \%)$ sesudah tanpa diberikan intervensi 1 mencit ( $6,2 \%)$ mengalami penurunan 
kadar glukosa ke dalam batas normal dan 15 mencit ( $93,8 \%$ ) mengalami penurunan kadar glukosa darah tapi belum ke dalam batas normal . Selisih penurunan kadar glukosa darah tertinggi yaitu sebesar $28 \mathrm{mg} / \mathrm{dl}$ dan selisih penurunan kadar glukosa darah terendah yaitu $3 \mathrm{mg} / \mathrm{dl}$.

Tabel 6 Analisis perbedaan kadar Glukosa Perlakuan dan kadar glukosa Kontrol

\begin{tabular}{|c|c|c|c|c|c|}
\hline \multirow{2}{*}{$\begin{array}{l}\text { Kode } \\
\text { sampel }\end{array}$} & \multicolumn{2}{|c|}{$\begin{array}{l}\text { Kadar glukosa perlakuan } \\
\text { (mg/dl) }\end{array}$} & \multirow[t]{2}{*}{$\begin{array}{l}\text { Kode } \\
\text { sampel }\end{array}$} & \multicolumn{2}{|c|}{ Kadar glukosa kontrol (mg/dl) } \\
\hline & Pre & Post & & Pre & Post \\
\hline P1 & $181 \mathrm{mg} / \mathrm{dl}$ & $114 \mathrm{mg} / \mathrm{dl}$ & K1 & $222 \mathrm{mg} / \mathrm{dl}$ & $194 \mathrm{mg} / \mathrm{dl}$ \\
\hline $\mathrm{P} 2$ & 179 mg/dl & $128 \mathrm{mg} / \mathrm{dl}$ & $\mathrm{K} 2$ & $185 \mathrm{mg} / \mathrm{dl}$ & $179 \mathrm{mg} / \mathrm{dl}$ \\
\hline P3 & 192 mg/dl & $145 \mathrm{mg} / \mathrm{dl}$ & K3 & $183 \mathrm{mg} / \mathrm{dl}$ & $178 \mathrm{mg} / \mathrm{dl}$ \\
\hline P4 & 226 mg/dl & $153 \mathrm{mg} / \mathrm{dl}$ & K4 & $180 \mathrm{mg} / \mathrm{dl}$ & $176 \mathrm{mg} / \mathrm{dl}$ \\
\hline P5 & $190 \mathrm{mg} / \mathrm{dl}$ & $128 \mathrm{mg} / \mathrm{dl}$ & K5 & 197 mg/dl & $187 \mathrm{mg} / \mathrm{dl}$ \\
\hline P6 & 176 mg/dl & $108 \mathrm{mg} / \mathrm{dl}$ & K6 & 209 mg/dl & $200 \mathrm{mg} / \mathrm{dl}$ \\
\hline P7 & $230 \mathrm{mg} / \mathrm{dl}$ & $179 \mathrm{mg} / \mathrm{dl}$ & K7 & $186 \mathrm{mg} / \mathrm{dl}$ & $179 \mathrm{mg} / \mathrm{dl}$ \\
\hline P8 & 187 mg/dl & $136 \mathrm{mg} / \mathrm{dl}$ & K8 & $190 \mathrm{mg} / \mathrm{dl}$ & $186 \mathrm{mg} / \mathrm{dl}$ \\
\hline P9 & $232 \mathrm{mg} / \mathrm{dl}$ & $185 \mathrm{mg} / \mathrm{dl}$ & K9 & $212 \mathrm{mg} / \mathrm{dl}$ & $205 \mathrm{mg} / \mathrm{dl}$ \\
\hline P10 & 189 mg/dl & $125 \mathrm{mg} / \mathrm{dl}$ & K10 & 197 mg/dl & $188 \mathrm{mg} / \mathrm{dl}$ \\
\hline P11 & 192 mg/dl & $103 \mathrm{mg} / \mathrm{dl}$ & K11 & $186 \mathrm{mg} / \mathrm{dl}$ & $174 \mathrm{mg} / \mathrm{dl}$ \\
\hline P12 & 192 mg/dl & $123 \mathrm{mg} / \mathrm{dl}$ & K12 & 194 mg/dl & $189 \mathrm{mg} / \mathrm{dl}$ \\
\hline P13 & 214 mg/dl & $156 \mathrm{mg} / \mathrm{dl}$ & K13 & $179 \mathrm{mg} / \mathrm{dl}$ & $176 \mathrm{mg} / \mathrm{dl}$ \\
\hline P14 & $234 \mathrm{mg} / \mathrm{dl}$ & $181 \mathrm{mg} / \mathrm{dl}$ & K14 & $188 \mathrm{mg} / \mathrm{dl}$ & $180 \mathrm{mg} / \mathrm{dl}$ \\
\hline P15 & $181 \mathrm{mg} / \mathrm{dl}$ & $110 \mathrm{mg} / \mathrm{dl}$ & K15 & $192 \mathrm{mg} / \mathrm{dl}$ & $181 \mathrm{mg} / \mathrm{dl}$ \\
\hline P16 & $185 \mathrm{mg} / \mathrm{dl}$ & $107 \mathrm{mg} / \mathrm{dl}$ & K16 & $199 \mathrm{mg} / \mathrm{dl}$ & $183 \mathrm{mg} / \mathrm{dl}$ \\
\hline Jumlah & 3180 & 2181 & Jumlah & 3099 & 2955 \\
\hline Mean & 198,75 & 136,3125 & Mean & 193,6875 & 184,6875 \\
\hline SD & 20,77338 & 27,48992 & SD & 12,0594 & 8,882333 \\
\hline $\begin{array}{l}\text { Uji ind } \\
\rho=0,0 C\end{array}$ & $\begin{array}{l}\text { ident samp } \\
\alpha=0,05\end{array}$ & tes & & & \\
\hline
\end{tabular}

Berdasarkan hasil penelitian diketahui bahwa, Pada penelitian ini dari 16 mencit (100\%) sesudah diberikan intervensi 13 mencit ( 81,2\%) mengalami penurunan kadar glukosa ke dalam batas normal dan 3 mencit ( $18,8 \%$ ) mengalami penurunan kadar glukosa darah tapi belum ke dalam batas norma . Hasil uji statistic dengan uji independent sample $t$ test, Hasil uji statistik menggunakan uji independent sample t-test menunjukkan hasil $\rho=0,000$, dengan tingkat kemaknaan 0,05 maka $\rho=0,000<\alpha 0,05$ sehingga $H_{1}$ diterima dan $\mathrm{H}_{0}$ ditolak artinya terdapat perbedaan kadar glukosa darah post test pada kelompok perlakuan dan kelompok kontrol. 


\section{PEMBAHASAN}

Identifikasi Kadar Glukosa Darah Sebelum Dan Sesudah Di Berikan Intervensi Ekstrak Bawang Hitam Pada Kelompok Perlakuan.

Hal ini sesuai dengan teori yang menyatakan bahwa senyawa aktif yang terkandung dalam bawang hitam dapat membantu penderita diabetes dengan mengkawal glukosa dalam darah dan meningkatkan sensitivitas insulin senyawa aktif ini yaitu flavanoid dan SAC, pada Bawang hitam kandungan SAC 2 kali lipat lebih tinggi dan tingkat DADS 30 kali lipat lebih tinggi dari bawang putih mentah ( Kim, 2012). Menurut Rizky (2015) banyak komponen berharga pada bawang hitam terutama polifenol, flavonoid, dan beberapa zat pada reaksi Maillard yang telah di kenal sebagai agen anti oksidan. Flavonoid dapat mengembalikan sensitifitas reseptor insulin pada sel sehingga menurunkan kadar glukosa darah, selain itu flavonoid sebagai antioksidan juga dapat memperbaiki sel $\beta$ pankreas yang telah rusak akibat radikal bebas. Di bandingkan dengan bawang putih, bawang hitam memiliki nutrisi yang lebih kaya dan peningkatan aktivitas biologis dan prospek aplikasi lebih luas ( Jung et al, 2014 ).

Pada bawang hitam di temukan bahwa total konten fenolik pada bawang hitam 5-8 kali lebih tinggi di bandingkan dengan bawang putih, sehingga bawang hitam memiliki aktivitas antioksidan lebih tinggi daripada bawang putih (Kimura et al, 2017). Tiga dari senyawa amadori dan senyawa Heyns di bawang hitam meningkat secara signifikan hingga 40-100 kali lipat lebih tinggi daripada bawang putih, sebaliknya melalui reaksi maillard bawang putih menjadi bawang hitam, rasa tidak sedap dan bau bawang putih mentah itu dihapus dengan menghambat transformasi alliin menjadi allicin sebagai inaktivasi panas alliinase.

Penelitian tentang ekstrak Bawang hitam (black garlic) memiliki antioksidan, anti-alergi, anti-diabetes, anti-inflamasi, hipokolesterolemik, hipolipidemik, dan efek antikarsinogenik. Dalam penelitian sebelumnya, konsumsi bawang putih liofilisasi pada tingkat $5 \%$ dari diet selama 7 minggu secara signifikan meningkatkan kadar insulin oleh $12,1 \%$ dan penurunan glukosa serum sebesar 8,7\% pada tikus $\mathrm{db} / \mathrm{db}$, sedangkan konsumsi bawang putih hitam berusia menurun secara signifikan model penilaian homeostasis resistensi insulin (HOMA-IR) sebesar $11,0 \%$ dan cenderung menurunkan kadar glukosa serum (Seo et al., 2009).

Berdasarkan hasil penelitian dan teori diatas peneliti berpendapat bahwa adanya 3 mencit yang mengalami 
penurunan kadar glukosa meskipun diberikan ekstrak bawang hitam tapi masih dalam keadaan hiperglikemia mungkin karena beberapa faktor di antaranya faktor genetik, respons fisiologis dan tingkat stress tiap mencit yang berbeda-beda dalam beradaptasi terhadap suntikan dextrosa $40 \%$ (Larantukan, 2014). Kedua faktor tersebut belum dapat dikendalikan oleh peneliti, sehingga perlu dibuktikan lebih lanjut pengaruh faktor genetik dan respons fisiologis mencit terhadap kadar glukosa darah.

Identifikasi Kadar Glukosa Darah Sebelum Dan Sesudah Di Berikan Intervensi Ekstrak Bawang Hitam Pada Kelompok Kontrol.

Secara fisiologis setelah pemberian glukosa, kadar glukosa darah meningkat dan mencapai puncaknya pada waktu 1 jam, kemudian turun ke kadar 2 jam. Pada keadaan fisiologis, insulin disekresikan sesuai dengan kebutuhan tubuh normal oleh sel beta. Sekresi insulin normal akan terjadi setelah adanya rangsangan seperti glukosa yang berasal dari makanan atau minuman. Insulin yang dihasilkan berfungsi mengatur regulasi glukosa darah agar selalu dalam batas fisiologis, baik saat puasa maupun setelah mendapat beban. Sekresi insulin berfungsi untuk menjaga kadar glukosa darah selalu dalam batas normal, sebagai cerminan metabolisme glukosa yang fisiologis (Sherwood, 2011). Rendahnya sensitivitas atau tingginya resistensi jaringan tubuh terhadap insulin dapat mempengaruhi metabolisme glukosa pada tubuh. Selain itu regulasi glukosa darah tidak hanya berkaitan dengan metabolisme glukosa di jaringan perifer, tapi juga di jaringan hepar dimana GLUT-2 berfungsi sebagai kendaraan pengangkut glukosa melewati membran sel kedalam sel. Dalam hal ini jaringan hepar ikut berperan dalam mengatur homeostasis glukosa tubuh (Weyer, 2000).

Berdasarkan hasil penelitian dan teori di atas peneliti berpendapat bahwa kadar glukosa darah mencit dengan tanpa pemberian intervensi ekstrak bawang hitam mengalami penurunan walaupun tidak sebesar penurunan pada kelompok perlakuan dapat juga dikarenakan faktor genetik, respons fisiologis dan tingkat stress tiap mencit yang berbeda-beda dalam beradaptasi terhadap suntikan dextrosa $40 \%$. Kedua faktor tersebut belum dapat dikendalikan oleh peneliti, sehingga perlu dibuktikan atau di lakukan penelitian lebih lanjut pengaruh faktor genetik dan respons fisiologis mencit terhadap kadar glukosa darah. 
Analisis Pemberian Ekstrak Bawang Hitam Terhadap Penurunan Kadar Glukosa Darah Pada Mencit.

Hal ini sesuai dengan teori yang menyatakan bahwa salah satu kandungan dari bawang hitam yaitu flavonoid mempunyai fungsi menghambat GLUT 2 mukosa usus sehingga dapat menurunkan absorbsi glukosa dan fruktosa dari usus

Rizky, 2015 ). Hasil penelitian yang di lakukan oleh Faisma Rosita (2016) tentang Pengaruh ekstrak bawang hitam (black garlic) terhadap penurunan kadar glukosa darah pada mencit (mus musculus) berdasarkan lama pemanasan.

Penelitian ini merupakan jenis true experimental laboratorie menggunakan RAL (rancangan acak lengkap) dengan 5 kelompok dengan dosis $500 \mathrm{mg} / \mathrm{KgBB}$. Penelitian ini menunjukkan bahwa ekstrak bawang hitam mengandung SAC, Polifenol, Flavanoid sebagai aktifitas antioksidan. Berdasarkan analisa One way Anova diperoleh hasil bahwa ekstrak bawang hitam memiliki aktifitas penurunan kadar glukosa darah namun belum efektif jika dibandingkan dengan glibenklamid.

Hasil penelitian ini diperkuat dengan adanya kelompok kontrol sebagai pembanding penurunan kadar glukosa darah antara kelompok yang diberi intervensi ekstrak bawang hitam dengan kelompok yang tidak diberi ekstrak bawang hitam. Menurut Marwanta (2017) bawang hitam (black garlic) sebagai pangan fungsional yang mengandung senyawa bioaktif yang bermanfaat bagi kesehatan dengan jumlah terstandar. Hasil uji toksisitas akut terhadap black garlic yang dihasilkan ini menunjukkan bahwa black garlic sangat aman. Kemudian black garlic ini diujikan kepada 200 relawan yang mempunyai keluhan diabetes dan 96\% penderita diabetes yang konsumsi mendapati penurunan kadar gula darah secara signifikan dalam waktu singkat (3-7 hari). Lima orang penderita diabetes dan selalu suntik insulin setiap hari menyatakan bahwa setelah konsumsi black garlic kadar insulin yang disuntikkan dikurangi oleh dokter.

Berdasarkan hasil penelitian dan teori diatas, adanya penurunan kadar glukosa darah di karenakan diberikan ekstrak bawang hitam selama 14 hari berturut-turut, dari 16 mencit pada kelompok perlakuan menunjukkan bahwa seluruh mencit mengalami penurunan tapi hanya 3 mencit yang mengalami penurunan tapi tidak ke dalam batas normal. Sedangkan pada kelompok kontrol dari 16 mencit pada kelompok kontrol menunjukkan bahwa semua mencit mengalami penurunan dan hanya 1 mencit yang mengalami penurunan kadar glukosa darah menjadi normal, ekstrak bawang hitam (black 
garlic) merupakan salah satu obat farmakologis dari tumbuh-tumbuhan yang mengandung antioksidan tinggi yang dapat menurunkan kadar glukosa darah pada mencit.

\section{Analisis Perbedaan Kadar Glukosa}

\section{Darah Pada Kelompok Perlakuan}

Hal ini sesuai dengan teori yang menyatakan bahwa salah satu kandungan dari bawang hitam yaitu flavonoid mempunyai fungsi menghambat GLUT 2 mukosa usus sehingga dapat menurunkan absorbsi glukosa dan fruktosa dari usus ( Rizky, 2015 ). Pada bawang hitam di temukan bahwa total konten fenolik pada bawang hitam 5-8 kali lebih tinggi di bandingkan dengan bawang putih, sehingga bawang hitam memiliki aktivitas antioksidan lebih tinggi daripada bawang putih ( Kimura et al, 2017 ). Tiga dari senyawa amadori dan senyawa Heyns di bawang hitam meningkat secara signifikan hingga 40-100 kali lipat lebih tinggi daripada bawang putih, sebaliknya melalui reaksi maillard bawang putih menjadi bawang hitam, rasa tidak sedap dan bau bawang putih mentah itu dihapus dengan menghambat transformasi alliin menjadi allicin sebagai inaktivasi panas alliinase.

Terjadinya perbedaan kadar glukosa darah sebelum diberikan intervensi ekstrak bawang hitam dan sesudah diberikan ekstrak bawang hitam dikarenakan pada bawang hitam memiliki kandungan antioksidan yang tinggi yang dapat menurunkan kadar glukosa darah pada mencit.

\section{Analisis Perbedaan Kadar Glukosa}

\section{Darah Pada Kelompok Kontrol}

Secara fisiologis setelah pemberian glukosa, kadar glukosa darah meningkat dan mencapai puncaknya pada waktu 1 jam, kemudian turun ke kadar 2 jam. Pada keadaan fisiologis, insulin disekresikan sesuai dengan kebutuhan tubuh normal oleh sel beta. Sekresi insulin normal akan terjadi setelah adanya rangsangan seperti glukosa yang berasal dari makanan atau minuman. Insulin yang dihasilkan berfungsi mengatur regulasi glukosa darah agar selalu dalam batas fisiologis, baik saat puasa maupun setelah mendapat beban. Sekresi insulin berfungsi untuk menjaga kadar glukosa darah selalu dalam batas normal, sebagai cerminan metabolisme glukosa yang fisiologis (Sherwood, 2011). Rendahnya sensitivitas atau tingginya resistensi jaringan tubuh terhadap insulin dapat mempengaruhi metabolisme glukosa pada tubuh. Selain itu regulasi glukosa darah tidak hanya berkaitan dengan metabolisme glukosa di jaringan perifer, tapi juga di jaringan hepar dimana GLUT-2 berfungsi sebagai kendaraan pengangkut glukosa melewati membran sel kedalam sel. Dalam hal ini jaringan 
hepar ikut berperan dalam mengatur homeostasis glukosa tubuh (Weyer, 2000; Kimura et al, 2017)

Berdasarkan hasil penelitian dan teori di atas bahwa hanya terdapat 1 mencit yang mengalami penurunan kadar glukosa darah ke dalam batas normal karena mencit tidak diberikan intervensi ekstrak bawang hitam dan secara fisiologis dan tingkat stress yang di alami mencit berbeda-beda.

\section{Analisis Perbedaan Kadar Glukosa \\ Darah Antara Kelompok Perlakuan Dan Kelompok Kontrol.}

Hasil ini sesuai dengan teori yang menyatakan bahwa Ekstrak bawang hitam mengandung SAC, Polifenol dan flavanoid sebagai antioksidan, Antioksidan dapat menekan apoptosis sel beta tanpa mengubah proliferasi dari sel beta pankreas. Menurut Rizky (2015) banyak komponen berharga pada bawang hitam terutama polifenol, flavonoid, dan beberapa zat pada reaksi Maillard yang telah di kenal sebagai agen anti oksidan. Flavonoid dapat mengembalikan sensitifitas reseptor insulin pada sel sehingga menurunkan kadar glukosa darah, selain itu flavonoid sebagai antioksidan juga dapat memperbaiki sel $\beta$ pankreas yang telah rusak akibat radikal bebas.

$$
\text { Menurut Eryuda }
$$

Antioksidan dapat mengikat radikal bebas, sehingga dapat mengurangi resistensi insulin. Mekanisme lain adalah kemampuan flavonoid terutama quercetin dalam menghambat GLUT 2 mukosa usus sehingga dapat menurunkan absorbsi glukosa. Hal ini menyebabkan pengurangan penyerapan glukosa dan fruktosa dari usus sehingga kadar glukosa darah turun. Flavonoid juga dapat menghambat fosfodiesterase sehingga meningkatkan cAMP pada sel beta pankreas. Peningkatan cAMP akan menstimulasi pengeluaran protein kinase A (PKA) yang merangsang sekresi insulin semakin meningkat.

Berdasarkan hasil penelitian di atas peneliti berpendapat bahwa terdapat perbedaan yang signifikan antara kelompok perlakuan dengan kelompok kontrol di karenakan pada kelompok perlakuan di berikan intervensi ekstrak bawang hitam dan pada kelompok kontrol tidak diberikan intervensi bawang hitam. Adanya mencit yang mengalami penurunan kadar glukosa darah tapi belum ke batas normal dikarenakan faktor genetik, respons fisiologis dan tingkat stress yang berbeda-beda.

\section{KESIMPULAN}

Ada perbedaan kadar glukosa darah sebelum dan sesudah diberikan intervensi ekstrak bawang hitam (black garlic) pada kelompok 
perlakuan , maupun pada kelompok control. Ada pengaruh pemberian ekstrak bawang hitam terhadap penurunan kadar glukosa darah pada mencit (mus musculus).

\section{DAFTAR PUSTAKA}

Bae, Sang Eun, et al. "Changes in S-allyl cysteine contents and physicochemical properties of black garlic during heat treatment." LWT-Food Science and Technology 55.1 (2014): 397-402.

Dalimartha, S., dan Adrian, F. (2012). Makanan \& Herbal Untuk Penderita Diabetes Mellitus. Jakarta: Penebar Swadatya. Hal. 5-14, 80-91.

Edwina, DA., Manaf, A., Efrida,et al. 2015. Pola Komplikasi Kronis Penderita Diabetes Melitus Tipe 2 Rawat Inap di Bagian Penyakit Dalam RS. Dr. M. Djamil Padang Januari 2011 Desember 2012. Jurnal Kedokteran Andalas.4(1): 102-106.

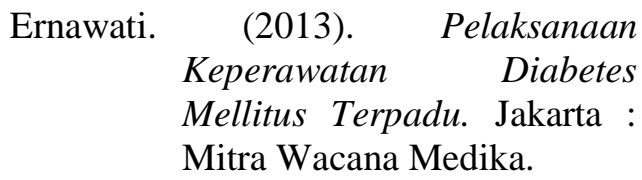

Eryuda, (2016). Mekanisme Antioksidan Jurnal Kedokteran
Jung, E. S., Park, S. H., Choi, E. K., Ryu, B. H., Park, B. H., Kim, D. S., Kim, Y. G., \& Chae, S. W. (2014). Reduction of blood lipid parameters by a 12-wk supplementation of aged black garlic:a randomized controlled trial. Nutrition (Burbank, Los Angeles County, Calif.),30 (9), 1034 1039. Pmid :2497 6429. http: //dx.doi.org /10.1016/ j.nut.2014.02.014.

Kasengke, J., Assa, Y.A., \& Paruntu, M.E. (2015). Gambaran Kadar Gula Darah Sesaat Pada Dewasa Muda Usia 2030 Tahun Dengan Indeks Massa Tubuh (IMT) $\geq 23$ $\mathrm{Kg} / \mathrm{m}^{2}$. Jurnal e-Biomedik (eBm), Vol. 3, No.3, SepDes 2015.

Kimura, Shunsuke, et al. "Black garlic: A critical review of its production, bioactivity, and application." Journal of food and drug analysis 25.1 (2017): 62-70.

Nursalam. (2016). Metodologi Penelitian Ilmu Keperawatan : Pendekatan Praktis Edisi 4. Jakarta : Salemba Medika

PERKENI. (2015). Konsensus pengelolaan dan pencegahan diabetes mellitus tipe 2 di Indonesia . Jakarta : Perkumpulan Endokrinologi Indonesia.

Rizky, B.A., 2015. White Dragon Fruit (Hylocereus undatus) Potential As Diabetes Mellitus Treatment, Artikel Review. J. Majority. 4(1): 69-72. 
Riset Kesehatan Daerah (Riskesdas) (2018). Badan Penelitian dan Pengembangan Kesehatan Kementrian RI tahun 2018.

Sato, E., Kohno, M., \& Hamano, H. (2006). Increased antioxidative potency of garlic by spontaneous short-term fermentation. Plant Foods for Human Nutrition, 61, $157 \mathrm{e} 160$.

Seo, Y. J., Gweon, O. C., Lee, Y. M., Kang, M. J., \& Kim, J. I. (2009). Effect of garlic and aged black garlic on hyperglycemia and dyslipidemia in animal model of type 2 diabetes mellitus. J Food Sci Nutr, 14(1), 1-7.
Sherwood, L. 2012. Fisiologi Manusia dari Sel ke Sistem. Edisi 6. Jakarta : EGC. h. 708-710.

Wang, D., Feng, Y., Liu, J., Yan, J.,Wang, M., Sasaki, J., et al. (2010). Black garlic (Allium sativum) extracts enhance the immune system. Medicinal and Aromatic Plant Science and Biotechnology, 4, 37e40. 